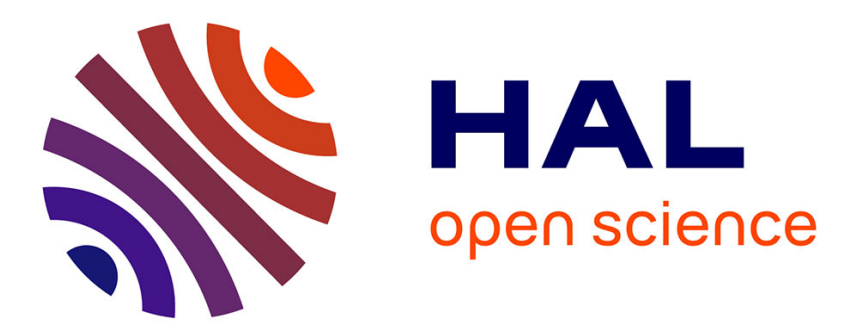

\title{
Poly(Adp-Ribose) Polymerase Signaling Of Topoisomerase 1-Dependent Dna Damage In Carcinoma Cells
}

Giovanna d'Onofrio, Filomena Tramontano, Annalisa Susanna Dorio, Alessia Muzi, Valeria Maselli, Domenico Fulgione, Grazia Graziani, Maria Malanga, Piera Quesada

\section{To cite this version:}

Giovanna d'Onofrio, Filomena Tramontano, Annalisa Susanna Dorio, Alessia Muzi, Valeria Maselli, et al.. Poly(Adp-Ribose) Polymerase Signaling Of Topoisomerase 1-Dependent Dna Damage In Carcinoma Cells. Biochemical Pharmacology, 2010, 81 (2), pp.194. 10.1016/j.bcp.2010.09.019 . hal00649892

\section{HAL Id: hal-00649892 \\ https://hal.science/hal-00649892}

Submitted on 9 Dec 2011

HAL is a multi-disciplinary open access archive for the deposit and dissemination of scientific research documents, whether they are published or not. The documents may come from teaching and research institutions in France or abroad, or from public or private research centers.
L'archive ouverte pluridisciplinaire HAL, est destinée au dépôt et à la diffusion de documents scientifiques de niveau recherche, publiés ou non, émanant des établissements d'enseignement et de recherche français ou étrangers, des laboratoires publics ou privés. 


\section{Accepted Manuscript}

Title: Poly(Adp-Ribose) Polymerase Signaling Of

Topoisomerase 1-Dependent Dna Damage In Carcinoma Cells

Authors: Giovanna D'Onofrio, Filomena Tramontano, Annalisa Susanna Dorio, Alessia Muzi, Valeria Maselli, Domenico Fulgione, Grazia Graziani, Maria Malanga, Piera

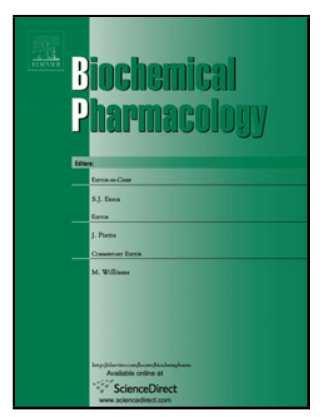

Quesada

PII:

S0006-2952(10)00702-1

DOI: doi:10.1016/j.bcp.2010.09.019

Reference: BCP 10724

To appear in: $\quad B C P$

Received date: $\quad 30-7-2010$

Revised date: $\quad 17-9-2010$

Accepted date: $\quad$ 20-9-2010

Please cite this article as: D'Onofrio G, Tramontano F, Dorio AS, Muzi A, Maselli V, Fulgione D, Graziani G, Malanga M, Quesada P, Poly(Adp-Ribose) Polymerase Signaling Of Topoisomerase 1-Dependent Dna Damage In Carcinoma Cells, Biochemical Pharmacology (2010), doi:10.1016/j.bcp.2010.09.019

This is a PDF file of an unedited manuscript that has been accepted for publication. As a service to our customers we are providing this early version of the manuscript. The manuscript will undergo copyediting, typesetting, and review of the resulting proof before it is published in its final form. Please note that during the production process errors may be discovered which could affect the content, and all legal disclaimers that apply to the journal pertain. 
POLY(ADP-RIBOSE) POLYMERASE SIGNALING OF TOPOISOMERASE 1DEPENDENT DNA DAMAGE IN CARCINOMA CELLS.

\author{
Giovanna D’Onofrio ${ }^{1}$, Filomena Tramontano ${ }^{1}$, Annalisa Susanna Dorio ${ }^{2}$, Alessia Muzi $^{2}$, \\ Valeria Maselli ${ }^{1}$, Domenico Fulgione ${ }^{1}$, Grazia Graziani ${ }^{2}$, Maria Malanga ${ }^{1}$, Piera Quesada ${ }^{1}$. \\ ${ }^{1}$ Department of Structural and Functional Biology, University Federico II of Naples, \\ ${ }^{2}$ Department of Neuroscience, University of Rome Tor Vergata, Italy
}

Running Title: Effects of PARP and TOP1 inhibitors in carcinoma cells

Key Words: Topotecan (TPT), PARP-1 and -2, PJ34 inhibitor, p53, carcinoma cells

Classification: Antibiotics and Chemotherapeutics 


\begin{abstract}
A molecular approach to enhance the antitumour activity of Topoisomerase 1 (TOP1) inhibitors relies on the use of chemical inhibitors of poly(ADP-ribose)polymerases (PARP). Poly(ADP-ribosyl)ation is involved in the regulation of many cellular processes such as DNA repair, cell cycle progression and cell death. Recent findings showed that poly(ADP-ribosyl)ated PARP-1 and PARP-2 counteract camptothecin action facilitating resealing of DNA strand breaks. Moreover, repair of DNA strand breaks induced by poisoned TOP1 is slower in the presence of PARP inhibitors, leading to increased toxicity.

In the present study we compared the effects of the camptothecin derivative Topotecan (TPT), and the PARP inhibitor PJ34, in breast (MCF7) and cervix (HeLa) carcinoma cells either PARP-1 proficient or silenced, both BRCA1/2 ${ }^{+/+}$and $\mathrm{p} 53^{+/+}$.

HeLa and MCF7 cell lines gave similar results: i) TPT-dependent cell growth inhibition and cell cycle perturbation were incremented by the presence of PJ34 and a 2 fold increase in toxicity was observed in PARP-1 stably silenced HeLa cells; ii) higher levels of DNA strand breaks were found in cells subjected to TPT+PJ34 combined treatment; iii) PARP-1 and -2 modification was evident in TPT-treated cells and was reduced by $\mathrm{TPT}+\mathrm{PJ} 34$ combined treatment; iv) concomitantly, a reduction of soluble/active TOP1 was observed. Furthermore, TPT-dependent induction of p53, p21 and apoptosis were found 24-72 $\mathrm{h}$ after treatment and were increased by PJ34 both in PARP-1 proficient and silenced cells. The characterization of such signaling network can be relevant to a strategy aimed at overcoming acquired chemoresistance to TOP1 inhibitors.
\end{abstract}




\section{INTRODUCTION}

The camptothecin derivative Topotecan (TPT) is a DNA Topoisomerase 1 (TOP1) inhibitor approved for the treatment of ovarian cancer, non small-cell lung cancer and under clinical investigation for a number of advanced solid tumours and haematological malignancies [1]. The drug reversibly abolishes the DNA religation activity of TOP1 generating single strand breaks (SSBs) to which the protein is covalently linked. Double strand breaks (DSBs) arise when replication forks collide with the SSBs and run off. Thus, TPT-induced DSBs are largely replication dependent or S phase specific [2, 3].

Eukaryotes have two pathways for repairing DSBs: homologous recombination (HR) and non homologous end joining (NHEJ). The relative contribution of these two DSB repair pathways seems to differ depending on the cell cycle phase; HR acts mainly in the S and G2 phases, whereas NHEJ mainly in the G1 phase $[4,5]$. For these reasons, TPTinduced replication-dependent DSBs are usually repaired by the HR pathway [6].

Poly(ADP-ribosyl)ation is a post-translational modification catalyzed by poly(ADPribose)polymerase-1 and -2 (PARP-1 and PARP-2) and is one of the earliest cellular responses to DNA damage. PARP-1 and PARP-2 belong to a family of enzymes that cleave $\beta-\mathrm{NAD}^{+}$in nicotinamide and ADP-ribose to form long and branched (ADPribose) polymers (PAR) on glutamic acid residues within the primary sequence of PARP1 and PARP-2 (automodification) and of other cellular proteins (heteromodification). This process causes chromatin decondensation around damage sites, recruitment of repair machineries, such as base excision repair complexes, and accelerates DNA damage repair [7, 8]. In contrast, when DNA damage exceeds cell repair capacity PARP-1 undergoes cleavage by caspases into two fragments of $89 \mathrm{kDa}$ and of $24 \mathrm{kDa}$, thereby avoiding futile cycling of PAR that would otherwise deplete the cell of $\beta-\mathrm{NAD}^{+}$required for the 
onset of apoptosis [9]. Moreover, interaction of PAR with the p53 oncoprotein is able to modulate its transcriptional activity [10].

PARP-1 also affects DSBs repair as indicated by the increased sensitivity of PARP-1deficient cells to DSBs inducing agents, especially to camptothecin [2]. Furthermore, the molecular mechanisms underlying tumour chemosensitization to TOP1 poisons by PARP inhibitors have been in part clarified by recent findings showing that poly(ADPribos)ylated PARP-1 and PARP-2 counteract camptothecin action facilitating resealing of DNA strand breaks [11]. This occurs through noncovalent yet specific interaction of PAR with particular TOP1 sites which results in inhibition of DNA cleavage and stimulation of the religation reaction [12]. Another mechanism proposed to explain the potentiation of campthotecin cytotoxicity by PARP inhibitors, is via the inhibition of base excision repair system, of which PARP-1 and -2 are important components. This model is supported by the association of tyrosyl phosphodiesterase-1, which removes the TOP1 cleavable complex, with base excision repair components that interact with PARP-1 [13].

Indeed, PARP-1 inhibition enhances the cytotoxic effects of TPT [14]. The potential of PARP inhibitors to increase the efficacy of chemotherapy has led to the development of a wide range of specific inhibitors -quinazolinone derivates- like NU1025 or PJ34 which display increased potency compared to the prototype 3-aminobenzamide (3-ABA) [15]. In this regard, we previously demonstrated a TPT-dependent PARP-1 activation in glioblastoma cells, while co-treatment with the PARP inhibitor NU1025 increased the TPT-dependent p53 up-regulation [16]. Moreover, we showed PJ34 chemo-potentiation of cisplatin in colon carcinoma cells [17].

It has been reported that PARP inhibitors would be particularly effective in BRCA1/2 mutated breast carcinoma cells [18]. In fact, PARP-1 and PARP-2 are required for the base excision repair pathway, whereas the BRCA proteins are critical for the HR 
pathway. Cells can survive when one repair system breaks down, but they start to die when both DNA repair mechanisms stop functioning.

Furthermore, a factor supposed to be involved in determining the sensitivity of cells to TOP1 inhibitors is p53. However, for breast cancer cells the p53 status was not found to be predictive of sensitivity to camptothecins [19].

On the basis of such evidences, we have investigated the role of PARP-1 in the DNA damage response to TOP1 inhibitors, in human $\mathrm{BRCA} 1 / 2^{+/+}$and $\mathrm{p} 53^{+/+}$mammary (MCF7) and cervix (HeLa) carcinoma cells treated with TPT as single agent or in association with a PARP inhibitor. Furthermore, TPT sensitivity of HeLa cells in which PARP-1 has been knocked down by RNA interference, has been compared to that of HeLa cells treated with the PARP inhibitor. 


\section{MATERIALS \& METHODS}

\subsection{Drugs, antibodies and chemicals}

TPT was from Glaxo Smith-Kline (Verona, Italy) and PJ34 [N- (6-oxo-5,6,dihydrophenanthridin-2-yl) - (N,Ndimethylamino) Acetamide] from Alexis Biochemicals (Vinci-Biochem, Firenze, Italy). The cocktail of protease inhibitors was from ROCHEDiagnostic (Milano, Italy).

Nicotinamide adenine [adenylate- $\left.{ }^{32} \mathrm{P}\right]$ dinucleotide- $\left[{ }^{32} \mathrm{P}\right]-\mathrm{NAD}^{+}(1,000 \mathrm{Ci} / \mathrm{mmole}, 10$ $\mathrm{mCi} / \mathrm{ml}$ ) was supplied by GE Healthcare (Milano, Italy).

Propidium iodide (PI) and RNAse were from Sigma-Aldrich (Milano, Italy).

PVDF (poly-vinylidene-fluoride) membrane was from MILLIPORE S.p.A. (Milano, Italy). Anti-PARP-1 mouse monoclonal antibody (F1-23) was from Alexis Biochemicals (Vinci-Biochem, Firenze, Italy) and anti-DNA TOP1 (Scl-70) human antibody from Topogen (ABCAM, Cambridge, UK). Anti-p53 (DO-1), anti-p21 (C-19), anti-BAX (P19) and anti-GAPDH (H-2) mouse monoclonal antibodies were from Santa-Cruz Biotechnology (DBA, Milano, Italy); anti-actin (A2066) mouse monoclonal antibody and goat anti-mouse and goat anti-rabbit IgG HRP-conjugated antibodies were from SigmaAldrich (Milano, Italy). Anti- $\gamma \mathrm{H} 2 \mathrm{AX}$ (ser139, 2577) rabbit antibody was from Cell Signaling (Invitrogen Milano, Italy).

All other chemicals were of the highest quality commercially available.

\subsection{Cell cultures}

Cervix (HeLa) and mammary (MCF7) carcinoma cells were maintained in Dulbecco's modified Eagle's medium (DMEM) containing 10\% (v/v) heat-inactivated foetal bovine serum (FBS), $100 \mathrm{U} / \mathrm{ml}$ penicillin, $100 \mathrm{~g} / \mathrm{ml}$ streptomycin, $5 \mathrm{mM} \mathrm{L}$ glutamine and incubated at $37^{\circ} \mathrm{C}$ in a humidified atmosphere, plus $5 \% \mathrm{CO}_{2}$. 
Stably PARP-1 silenced HeLa cells (hereafter referred to as $\mathrm{HeLa}^{\mathrm{SiP}-1}$ ) or transfected with the pBabe vector carrying the puromycin resistance gene (hereafter referred to as $\mathrm{HeLa}^{\mathrm{Babe}}$ ) were obtained as previously described [20].

\subsection{Cell growth inhibition}

MCF7 and HeLa cells were seeded at $1 \times 10^{5}$ cells; after $24 \mathrm{~h}$, cell cultures were treated with graded concentrations of TPT and PJ34 and cell growth inhibition was assessed at different time points $(24,48,72 \mathrm{~h})$ using the 3-[4,5-dimethylthiazol-2-yl]-2,5diphenyltetrazolium bromide (MTT) assay. All the experiments were performed in triplicate.

\subsection{Cytofluorimetric analysis}

Control and treated cells were detached by enzymatic treatment (Trypsin/EDTA $0.02 \%$ ), washed in PBS w/o $\mathrm{Ca}^{++} / \mathrm{Mg}^{++}$pooled with floating cells and recovered by centrifugation at $1,200 \mathrm{rpm}$ for $15 \mathrm{~min}$ at $4^{\circ} \mathrm{C}$. Cells were fixed in $70 \%$ ethanol and stored at $-20^{\circ} \mathrm{C}$ until analysis. After washing in PBS w/o $\mathrm{Ca}^{++} / \mathrm{Mg}^{++}$, cells were stained in $2 \mathrm{ml}$ of propidium iodide (PI) staining solution [50 $\mu \mathrm{g} / \mathrm{ml}$ of PI, $1 \mathrm{mg} / \mathrm{ml}$ of RNAse A in PBS w/o $\left.\mathrm{Ca}^{++} / \mathrm{Mg}^{++}, \mathrm{pH} 7.4\right]$ overnight at $4^{\circ} \mathrm{C}$ and DNA flow cytometry was performed in duplicate by a FACScan flow cytometer (Becton Dickinson Franklin Lakes, NJ USA) coupled with a CICERO work station (Cytomation). Cell cycle analysis was performed by the ModFit LT software (Verity Software House Inc. Topsham, ME USA). FL2 area versus FL2 width gating was done to exclude doublets from the G2/M region. For each sample 15,000 events were stored in list mode file.

\subsection{Alkaline Comet Assay}


Cells were suspended in PBS at a density of $10^{4}$ cells $/ \mathrm{ml}$ and mixed with an equal volume of fresh low-melting agarose (LMA, $1 \%$ in PBS); $80 \mu$ l of agarose cell suspension was spread on normal-melting agarose (NMA, 1\% in PBS) slides and covered with a cover-slip. Two slides were prepared per sample. After gelling for $5 \mathrm{~min}$ on an ice bed, the cover-slip was gently removed and another layer was added, cover-slipped and allowed to solidify for $5 \mathrm{~min}$ on ice before gently removing the cover-slip. The slides were then immersed in a freshly prepared ice-cold lysis solution $(2.5 \mathrm{M} \mathrm{NaCl}, 0.1 \mathrm{M}$ $\mathrm{Na}_{2}$ EDTA, $0.01 \mathrm{M}$ Tris, $1 \%$ Triton X-100, 10\% DMSO, $\mathrm{pH} 10$ ) for $1 \mathrm{~h}$. The slides were drained and placed in a horizontal electrophoresis tank filled with freshly prepared alkaline buffer (0.3 M NaOH, $1 \mathrm{mM} \mathrm{Na} 2$ EDTA, $\mathrm{pH} 13)$. Electrophoresis was carried out in this buffer for $20 \mathrm{~min}$ at $300 \mathrm{~mA}$. Finally, the slides were gently washed twice in a neutralization buffer (Tris- $\mathrm{HCl} 0.4 \mathrm{M}, \mathrm{pH} 7.5$ ) for 5 minutes to remove alkali and detergent, and stained with $50 \mu \mathrm{l} / \mathrm{ml}$ DAPI $(3 \mathrm{~h})$. Images of a minimum of hundred cells from each sample were analysed on a fluorescence microscope (Nikon Instruments S.p.A. Firenze, Italy); overlapping figures were avoided from each slide. Quantitative assessment of DNA damage was performed using Comet Score 1.5 Image Analysis (TriTek Corporation, Sumerduck VA, USA) software which computes the integrated intensity profile for each cell. DNA damage was measured as olive tail moment [(Tail mean - Head mean) x \% of DNA in the tail/100]. The results were analysed by Student's $t$-test and were considered statistically significant at $\mathrm{P}<0.008$.

\subsection{Analysis of $\left[{ }^{32} \mathrm{P}\right]-\mathrm{PAR}$ synthesis}

Following treatment with $10 \mu \mathrm{M}$ TPT $+/-5 \mu \mathrm{M}$ PJ34 of intact cell $\left(5 \times 10^{6}\right.$ cells/plate $)$, $\left[{ }^{32} \mathrm{P}\right]-\mathrm{PAR}$ synthesis was determined by substituting the culture medium with $1 \mathrm{ml}$ of 56 mM HEPES buffer $\mathrm{pH} 7.5$, containing $28 \mathrm{mM} \mathrm{KCl}, 28 \mathrm{mM} \mathrm{NaCl}, 2 \mathrm{mM} \mathrm{MgCl} 2,0.01 \%$ 
digitonin, $0.1 \mathrm{mM}$ PMSF, 1:25 dilution of a cocktail of protease inhibitors, $0.125 \mu \mathrm{M}$ $\mathrm{NAD}^{+}$and $5 \mu \mathrm{Ci}\left[{ }^{32} \mathrm{P}\right]-\mathrm{NAD}^{+}(1,000 \mathrm{Ci} / \mathrm{mmole})$. After incubation at $37^{\circ} \mathrm{C}$ for $30 \mathrm{~min}$, cells were scraped off the plates, transferred to eppendorf tubes and mixed with TCA at 20\% (w:v) final concentration. After 15 min standing on ice, samples were collected by centrifugation at 1,200 rpm for $15 \mathrm{~min}$, washed twice with 5\% TCA and three times with ethanol. $\left[{ }^{32} \mathrm{P}\right]-\mathrm{PAR}$ incorporated in the TCA-insoluble fraction was measured by Cerenkov counting using a LS8100 liquid scintillation spectrometer (Beckman Coulter S.p.A. Milano, Italy). Finally, TCA protein pellets were resuspended in Laemmli buffer; proteins were separated by $5-15 \%$ SDS-PAGE and after electroblotting on PVDF membrane, $\left[{ }^{32} \mathrm{P}\right]-\mathrm{PAR}$ acceptors were visualized by autoradiography. Immunodetection of specific proteins was accomplished on the same blots after autoradiography.

PJ34 efficiency as PARP inhibitor, was determined in an in vitro enzymatic activity assay using permeabilized cells: cell pellets were resuspended in $40 \mathrm{mM}$ Tris- $\mathrm{HCl} \mathrm{pH}$ 7.8, $0.6 \mathrm{mM}$ EDTA, $30 \mathrm{mM} \mathrm{MgCl}_{2}, 0.05 \%$ Triton X-100, $1 \mathrm{mM} \beta$-mercaptoethanol, $20 \%$ glycerol, $1 \mathrm{mM}$ PMSF and a 1:25 dilution of the cocktail of protease. To maximally stimulate PAR synthesis, DNA strand breaks were induced by sonication for $30 \mathrm{sec}$ at medium intensity; finally, samples were incubated at $30^{\circ} \mathrm{C}$ for $1 \mathrm{~h}$ with $5 \mu \mathrm{Ci} / \mathrm{ml}\left[{ }^{32} \mathrm{P}\right]-$ $\mathrm{NAD}^{+}$and $50 \mu \mathrm{M}$ unlabeled $\beta-\mathrm{NAD}^{+}$, in the presence or absence of $5 \mu \mathrm{M}$ PJ34.

Reactions were stopped by TCA addition ( $20 \%$ final concentration) and the samples were processed and analyzed as described above.

\subsection{Isolation of nuclear and post-nuclear fractions}

To isolate sub-cellular fractions, cells were suspended in a buffer containing $30 \mathrm{mM}$ Tris- $\mathrm{HCl} \mathrm{pH}$ 7.5, $1.5 \mathrm{mM} \mathrm{MgCl} 2,10 \mathrm{mM} \mathrm{KCl,} 1 \%$ (v/v) Triton X-100, $20 \%$ glycerol, 2 mM PMSF and the protease inhibitors cocktail solution. After 30 min of incubation on 
ice, cellular suspensions were centrifuged at $960 \mathrm{x} \mathrm{g}$ for $90 \mathrm{sec}$ at $4{ }^{\circ} \mathrm{C}$ and the nuclear fractions recovered in the pellet. The supernatant represents the post-nuclear fraction.

Nuclear fractions were resuspended in $20 \mathrm{mM}$ HEPES pH 7.9, containing $20 \mathrm{mM}$ $\mathrm{KCl}, 0.2 \mathrm{mM}$ EDTA, $1.5 \mathrm{mM} \mathrm{MgCl}_{2}, 25 \%$ glycerol and the protease inhibitors cocktail solution. Protein concentration was determined using the Bradford protein assay reagent (BIO-RAD Milano, Italy) with bovine serum albumin as a standard.

\subsection{Autoradiographic and immunological analyses}

Aliquots of $120 \mu \mathrm{g}$ of cellular proteins were separated by SDS-PAGE (5-15\% gradient gels) and transferred onto a PVDF membrane using an electroblotting apparatus (BIO-RAD). The membrane was subjected to autoradiographic analysis by the PhosphorImager (BIO-RAD) and/or to immunodetection after blocking with 5\% non-fat milk in TBST $1 \mathrm{~h}$, with anti-PARP-1 (F1-23; diluted 1:5,000), anti-TOP1 (Scl-70; diluted 1:2,500), anti-p53 (DO-1; diluted 1:5,000), anti-p21 (C-19; diluted 1:1,000), anti-Bax (P19; diluted 1:500), anti-GAPDH (H2; diluted 1:5,000), anti- $\gamma \mathrm{H} 2 \mathrm{AX}$ (2577; diluted 1:1,000) and anti-actin (A2066; diluted 1:1,000).

As secondary antibodies goat-anti-mouse or goat-anti-rabbit IgG HRP-conjugate (diluted $1: 10,000-1: 20,000)$ in $3 \%(\mathrm{w} / \mathrm{v})$ non-fat milk in TBST were used. Peroxidase activity was detected using the ECL Advance Western Blotting Kit of GE Healthcare (Milano, Italy) and quantified using the Immuno-Star Chemiluminescent detection system GS710 (BIO-RAD) and the Arbitrary Densitometric Units normalised on those of the GAPDH loading control. 


\section{RESULTS}

\subsection{Effect of PJ34 on TPT-induced growth inhibition in human carcinoma cells}

In preliminary experiments human cervical (HeLa) and mammary (MCF7) carcinoma cell lines showed comparable TPT-dependent growth inhibition, as measured by the MTT assay (data not shown). Furthermore, PARP-1 silencing by stable shRNA expression in HeLa cells $\left(\mathrm{HeLa}^{\mathrm{SiP}-1}\right)$ rendered these cells more sensitive to the cytotoxic effects of the drug. In particular, while in a $72 \mathrm{~h}$ assay, $10 \mu \mathrm{M}$ TPT for $1 \mathrm{~h}$ exerted mainly cytostatic effects in control cells $\left(\right.$ Hela $\left.^{\text {Babe }}\right)$, the same treatment caused $45 \%(+/-5)$ of PARP-1 silenced cells $\left(\mathrm{HeLa}^{\mathrm{SiP}-1}\right)$ to die. In the presence of $5 \mu \mathrm{M}$ PJ34 $30 \%(+/-6)$ of PARP-1 proficient and $60 \%(+/-9)$ of PARP-1 deficient cells underwent cell death (data not shown).

To gain insight into the mechanism of enhanced TPT toxicity as a consequence of alteration of the cellular poly(ADP-ribosyl)ation status, we analysed cell cycle distribution at different recovery times after $1 \mathrm{~h}$ exposure to increasing concentrations of TPT, in the presence or absence of a functional PARP-1 (i.e., PARP-1 wild type HeLa or MCF7 cells versus $\mathrm{HeLa}^{\mathrm{SP}-1}$ cells). In another set of experiments, the PARP inhibitor PJ34 was used in combination with TPT, at a fixed concentration of $5 \mu \mathrm{M}$, maintained in the culture medium all over the recovery time. As shown in Figure 1, as early as $24 \mathrm{~h}$ after treatment, graded concentrations of TPT induced a progressive increase of cell accumulation in the $\mathrm{G} 2 / \mathrm{M}$ phase starting from $0.2 \mu \mathrm{M}$ up to $1.25 \mu \mathrm{M}$. Higher TPT concentrations, instead, promptly arrested the cells in S phase.

The addition of the PARP inhibitor PJ34 to TPT concentrations $<1.25 \mu \mathrm{M}$ significantly increased G2/M cell accumulation, whereas when combined with $\geq 1.25 \mu \mathrm{M}$ TPT concentrations, PJ34 induced S phase cell accumulation. As also shown in Figure 1 
cell cycle kinetics was unaffected by treatment of $\mathrm{HeLa}^{\mathrm{Babe}}$ cells with PJ34 used as single agent.

$\mathrm{HeLa}^{\mathrm{SP}-1}$ cells treated with TPT concentrations comprised between 0.2 and $0.4 \mu \mathrm{M}$ underwent a more pronounced increase of $\mathrm{G} 2 / \mathrm{M}$ cell accumulation with respect to $\mathrm{Hela}^{\mathrm{Babe}}$ cells exposed to the same concentrations of the TOP1 poison. Interestingly, 0.4 $\mu \mathrm{M}$ TPT caused in $\mathrm{HeLa}^{\mathrm{SiP}-1}$ cells effects comparable to those observed in $\mathrm{HeLa}^{\mathrm{Babe}}$ cells treated with $0.4 \mu \mathrm{M}$ TPT plus the PARP inhibitor. However, PARP-1 silenced cells retained sensitivity to PJ34 and the combination $1.25 \mu \mathrm{M}$ TPT+PJ34 caused S phase accumulation at a higher extent in $\mathrm{HeLa}^{\mathrm{SiP}-1}$ than in $\mathrm{Hela}^{\mathrm{Babe}}$ cells (Figure 1).

Cytofluorimetric analyses at a longer recovery time (i.e., $72 \mathrm{~h}$ after treatment), revealed that alterations of the poly(ADP-ribosyl)ation system caused TPT to be cytotoxic at a concentration $(1.25 \mu \mathrm{M})$ that was primarily cytostatic in control cells, as indicated by the appearance of a sub-diploid peak (apoptotic cells) both in PARP-1 silenced $\left(\mathrm{HeLa}^{\mathrm{SP}-1}\right.$ ) and PJ34-treated PARP-1 wild type cells (Hela ${ }^{\mathrm{Babe}}$ ) (Figure 2). In this regard, the lack of PARP-1 appeared to be more effective than PARP activity inhibition as the fraction of apoptotic cells was $62 \%$ in TPT-treated $\mathrm{HeLa}^{\mathrm{SiP}-1}$ versus $38 \%$ in $\mathrm{HeLa}^{\mathrm{Babe}}$, subjected to a combined TPT+PJ34 treatment (Figure 2).

\subsection{Analysis of TPT and/or PJ34 dependent DNA damage in carcinoma cells}

By alkaline comet assay, we analysed the level of both SSBs and DSBs [21] induced by $10 \mu \mathrm{M}$ TPT+/-PJ34 treatments. Figure $\mathbf{3 A}$ shows that the olive tail moment determined for both HeLa (Babe and SiP-1) and MCF7 cells $24 \mathrm{~h}$ after $1 \mathrm{~h}$ treatment with TPT was increased in the cells left to recover in the presence of PJ34. The definition of a DSBs level was obtained by looking at the H2AX phoshorylation in isolated nuclei from Babe and SiP-1 cells. Figure 3B shows that $72 \mathrm{~h}$ after $1 \mathrm{~h}$ treatment TPT induced a 
higher level of histone phosphorylation in $\mathrm{HeLa}^{\mathrm{SiP}-1}$ than in Hela ${ }^{\text {Babe }}$ cells. H2AX phoshorylation was further incremented by PJ34 addition in both PARP-1 proficient and silenced cells.

\subsection{Analysis of PAR synthesis in carcinoma cells after treatment with TPT $+/-$ PJ34}

First, PJ34 efficacy as a PARP inhibitor at the concentration used in this study was assessed in an in vitro enzyme activity assay by incubating permeabilized and sonicated HeLa cells with exogenous $50 \mu \mathrm{M}\left[{ }^{32} \mathrm{P}\right]-\mathrm{NAD}^{+}$in the presence or not of $5 \mu \mathrm{M}$ PJ34. Sonication was performed to induce DNA strand breaks and thus maximally stimulate endogenous PARP activities. PAR synthesis on protein acceptors was analyzed by SDSPAGE followed by electroblotting onto PVDF membrane and autoradiography. As shown in Figure 4A, a high amount of protein-bound PAR was produced in HeLa cells and such an activity was completely inhibited by $5 \mu \mathrm{M}$ PJ34. Although a wide range of modified proteins could be visualized, the main PAR acceptor was most likely PARP-1 as suggested by the strong radioactivity signal at the top of the gel and by the concomitant reduction of the PARP-1 immunoreactive band in the sample incubated with $\beta-\mathrm{NAD}^{+}$alone compared to that incubated with $\beta-\mathrm{NAD}^{+}$and PJ34 (Figure 4B). Such a difference is explained by a band depletion due to the automodification-related electrophoretic mobility shift of a fraction of heavily poly(ADP-ribosylated) PARP-1. After quantification of immunoreactive bands by scanning densitometry and normalization of PARP-1 to GAPDH content it could be estimated that about 50\% of PARP-1 underwent automodification.

The same kind of analysis carried out in $\mathrm{HeLa}^{\mathrm{SiP}-1}$ cells, revealed a strongly reduced ADP-ribosylation capacity of these cells as a consequence of PARP-1 silencing (Figure 
4A): on the autoradiography only a light smear at the top of the gel could be visualized. As no PARP-1 could be detected in these cells by western blotting (Figure 4B) the modest ADP-ribosylation activity detected by the in vitro assay may be due to PARP-2 and/or other PARP.

Then, we used a different experimental setting to determine whether or not TPT could induce PARP(s) activation in intact cells. To this purpose, growing MCF7 cells were first exposed to the drugs and then PAR synthesis was measured in situ by incubation in the presence of $0.01 \%$ digitonin and $0.125 \mu \mathrm{M}\left[{ }^{32} \mathrm{P}\right]-\mathrm{NAD}^{+}$. By autoradiography (Figure 5A) we observed a main signal slightly up to PARP-1 molecular weight (113 kDa), indicating that DNA damage induced by TPT caused PARP-1 activation and automodification that was apparent already after $1 \mathrm{~h}$ treatment and further increased in the following $24 \mathrm{~h}$ recovery time. Such a trend was confirmed by scanning densitometry and normalization of data from autoradiography (Figure 5A) to those relative to PARP-1 immunoreactive band (Figure 5B). Minor autoradiographic bands were evident in the 90-50 kDa MWs range (Figure 5A) indicating other PAR acceptors, possibly including other PARP. PARP-2 was detectable in this region as a $62 \mathrm{kDa}$ protein band; a modification-related electrophoretic mobility shift could explain the lack of correspondence between the autoradiographic signal (Figure 5A) and the PARP-2 immunoreactive band (Figure 5B).

The autoradiographic signals were drastically reduced (up to $75 \%$ reduction) in cells co-treated with TPT and the PARP inhibitor with respect to cells treated with TPT as single agent.

Similar results were obtained in $\mathrm{HeLa}^{\text {Babe }}$ cells, while a $\left[{ }^{32} \mathrm{P}\right]-\mathrm{PAR}$ signal was undetectable in $\mathrm{HeLa}^{\mathrm{SiP}-1}$ (data not shown). 


\subsection{Immunological analysis of PARP-1, TOP1, p53, p21 level in TPT+/-PJ34} treated cells

By western blotting we analysed changes in the endogenous levels of PARP-1, TOP1 and p53 in HeLa and MCF7 cells at different times (24, 48 and 72 h) after treatment with TPT+/-PJ34.

Figure 6 shows a comparable amount of PARP-1 in MCF7 cell samples at all time points, whereas the amount of soluble/active TOP1 was lowered $(\sim 50 \%)$ till $72 \mathrm{~h}$ after treatment with TPT alone or in combination with PJ34. Conversely, an up-regulation of p53 endogenous levels was evident until $72 \mathrm{~h}$ after treatment with TPT+/-PJ34. Furthermore, the p53-dependent p21 induction was evidenced starting from $24 \mathrm{~h}$ after TPT treatment.

Figure 7 shows that the amount of soluble/active TOP1 was drastically lowered also in HeLa cells (up to 70\%-80\% reduction both in PARP-1 proficient and silenced cells) as a consequence of the treatments. Interestingly, such a decrease was sustained till $72 \mathrm{~h}$ after $1 \mathrm{~h}$ treatment.

Again, we observed a TPT-dependent p53 up-regulation in both PARP-1 proficient and silenced cells, which appeared further increased by the use of PARP inhibitor (Figure 7).

By densitometric scanning of immunoreactive bands we quantified the changes in p53 levels at different times after single and combined treatments. As shown in Figure 8, the p53 level was 2-4 fold increased in $\mathrm{HeLa}^{\text {Babe }}$ cells $72 \mathrm{~h}$ after $1 \mathrm{~h}$ TPT-/+PJ34 treatment. In $\mathrm{HeLa}^{\mathrm{SiP}-1}$ cells a 10 fold increase was induced by TPT alone and this value increased (13 fold) in the presence of PJ34 during the recovery time.

Finally, $72 \mathrm{~h}$ after TPT treatment we analysed the expression of apoptotic markers. Figure 9 shows in $\mathrm{HeLa}^{\text {Babe }}$ cells the caspase-dependent PARP-1 cleavage. In MCF7 
1 


\section{DISCUSSION}

The evaluation of PARP inhibitors as chemosensitizers is based on evidences linking PARP-1 and recently PARP-2, to the cellular DNA damage response [13]. This has led to the development of a multitude of potent inhibitors with various bioavailability and pharmacokinetic characteristics whose efficacy in the treatment of cancer in vivo has been evaluated in animal models $[14,22]$; several PARP inhibitors are currently under investigation in clinical trials $[15,23]$. However, a clear understanding of the mechanism(s) whereby PARP inhibitors potentiate the activity of antineoplastic agents is still lacking. Moreover, isoform specific PARP inhibitors are still missing while it is known that PARP-2 accounts for 10-20\% of the total PARP activity in response to DNA damage [24 and references therein].

In our studies we used the hydrophilic PARP inhibitor PJ34 that has been recently reported to synergize with cisplatin in triple-negative breast cancer cells [25], in combination with the DNA TOP1 inhibitor, TPT. For our experiments we performed $1 \mathrm{~h}$ treatment with up to $10 \mu \mathrm{M}$ TPT that was already reported to be sufficient for trapping TOP1 in MCF7 cells [26]. PJ34 was used at a concentration $(5 \mu \mathrm{M})$ that was capable of inhibiting PARP activity but devoid of cytotoxic effects We found that TPT toxicity was higher when PAR synthesis was strongly reduced by either PARP-1 silencing (HeLa ${ }^{\text {Sip-1 }}$ cells) or PJ34 administration (both in HeLa and MCF7 cells).

MCF7 and HeLa cells, according with their comparable PARP- ${ }^{+/+}$BRCA1/2 ${ }^{+/+}$and $\mathrm{p} 53^{+/+}$status showed the same sensitivity to TPT, which determined a cell cycle arrest until $72 \mathrm{~h}$ after treatment. However, in combination with PJ34, TPT was cytotoxic even at a very low concentration $(1.25 \mu \mathrm{M})$. Accordingly, $1.25 \mu \mathrm{M}$ TPT alone was cytotoxic in PARP-1 silenced cells (HeLa ${ }^{\mathrm{SiP}-1}$ ). Nevertheless, the PARP inhibitor further increased the sensitivity of SiP-1 cells with respect to PARP-1 proficient cells treated with the drug 
combination, suggesting a PARP-2 involvement in the signaling of TPT-dependent DNA damage.

Consistently with the idea that poly(ADP-ribosyl)ation plays a role in the response to TPT-induced DNA damage, we found increased PAR synthesis following cell exposure to $10 \mu \mathrm{M}$ TPT. The PARP inhibitor PJ34 prevented PARP activity and concomitantly caused intensification of cell cycle perturbations and increased DNA damage.

In particular, we observed distinct cell cycle perturbation effects depending on the concentration of the TOP1 inhibitor and on the association with the PARP inhibitor: in the low TPT dose range, PJ34 in combination with 0.2-0.4 $\mu \mathrm{M}$ TPT caused more cells to be arrested in the G2/M phase, whereas combined with $1.25 \mu \mathrm{M}$ TPT it arrested at the $\mathrm{S}$ phase cells that escaped TPT action. Furthermore, the G2/M block induced by $0.4 \mu \mathrm{M}$ TPT in PARP-1 wild type cells was magnified in PARP-1 silenced HeLa cells. These evidences agree with the concept that after $1 \mathrm{~h}$ pulse (whatever the dose) of TPT not all the cells are prevented from entry in mitosis and then G2 cell lineages could survive TPT-mediated cytotoxicity [27]. Therefore, accumulation at the G2/M phase of tumour cells that escaped TPT action, provoked by PARP inhibition or by PARP-1 silencing, can be seen as a mechanism to overcome resistance to camptothecin derivatives. Interestingly, in PARP-1 silenced HeLa cells PJ34 increased the TPT S phase arrest as a further indication of PARP-2 implication.

Consistently, the TPT-dependent DNA damage level was increased by co-treatment with PJ34 either in PARP-1 proficient and PARP-1 silenced cells $24 \mathrm{~h}$ after treatment. In nuclei of such cells, differences in $\gamma \mathrm{H} 2 \mathrm{AX}$ levels deriving from TPT+/-PJ34, also support PARP-1 and -2 stimulation of TPT-dependent DSBs repair.

Moreover, we found a sustained PAR synthesis from 1 to $24 \mathrm{~h}$ after treatment and most of the newly synthesized polymer was linked to PARP-1 itself. Two other PAR 
acceptors in the 55-95 kDa MW's range appeared to be TPT- and PJ34-dependent. Accordingly with the magnified effects of TPT+PJ34 treatment in PARP-1 silenced cells the PARP-2 modification could represent the mechanism of its participation in DSBs signaling and HR repair [24].

Indeed, these evidences suggest that the lack of PAR synthesis, by interfering with the repair of TOP1-induced DNA damage, causes DNA strand breaks accumulation and further delays cell cycle progression. Moreover, we found that TPT-treated cells entered the apoptotic program as a consequence of PARP-1 silencing and/or PARP inhibition.

The last set of results was based on mechanistic investigations addressed to show the long-term response to TPT action: after $1 \mathrm{~h}$ TPT pulse TOP1 soluble/active fraction was drastically reduced for at least 3 cell duplication cycles and p53/p21 levels increased within the same time frame. Such an up-regulation was even higher in cells lacking PARP-1 and further increased by TPT+PJ34 treatment, supporting again the involvement of PARP-2 in the signaling of TPT-dependent DNA damage.

These results are in agreement with those previously reported in the same cells treated with the methylating agent temozolomide in combination with the PARP inhibitor GPI 15427, suggesting the involvement of PARP-2 (or other PARP) in the repair of DNA damage provoked by temozolomide [20].

Our data also suggest a synergistic interaction of PARP-1 and PARP-2 with p53 in tumour suppression through their role in DNA damage response and genome integrity surveillance. Another study showed that in MCF7 cells inhibition of endogenous PARP-1 function suppresses the transactivation function of p53 in response to ionizing radiation [28]. We also observed that p53-dependent BAX expression and caspase-dependent PARP-1 proteolysis were sustained by the PARP inhibitor as a result of apoptosis induction. 
By the all of such evidences we envisaged a TPT-dependent DNA damage signaling network, involving PARP. Indeed, the DNA damage arising from the trapping of TOP1 was signaled by PARP-1 and -2 and gathered by effectors like p53 and p21. Previous results suggest that p53 causes resistance of cells to TPT [29]. Our findings suggest a PARP modification induced by TPT-dependent DNA damage, while PARP-1 and -2 inactivation switches on $\mathrm{p} 53 / \mathrm{p} 21$ pro-apoptotic role.

Indeed, caspase-dependent PARP-1 proteolysis contributes to restoring the apoptotic program in neoplastic cells. Nuclear caspases-mediated PARP-1 cleavage has been described in camptothecin-induced apoptosis as an early event that precedes the release of cytochrome c and AIF, generally thought to activate the chemotherapy-induced apoptosis by DNA-damaging drugs [30].

In conclusion, our findings contribute to the understanding of the molecular events triggered by TOP1 poison-dependent genomic damage and provide a rationale for the development of new approaches to sensitize cancer cells to chemotherapy.

\section{ACKNOWLEDGEMENTS:}

This work was supported by funding from the Italian Ministery of Education and Research "Programmi di Ricerca Scientifica di Rilevante Interesse Nazionale" (PRIN 2007-2009). 


\section{REFERENCES}

1. Pommier Y. Topoisomerase I inhibitors: camptothecins and beyond. Nat Rev Cancer 2006;6:789-802.

2. Staker BL, Hjerrild K, Feese MD, Behnke CA, Burgin AB Jr, Stewart L. The mechanism of topoisomerase I poisoning by a camptothecin analog. Proc Natl Acad Sci USA 2002;99:15387-92.

3. Pommier Y, Redon C, Rao VA, Seiler JA, Sordet O, Takemura H et al. Repair of and checkpoint response to topoisomerase I-mediated DNA damage. Mutat Res 2003;532:173203.

4. Takata M, Sasaki MS, Sonoda E, Morrison C, Hashimoto M, Utsumi H et al. Homologous recombination and non-homologous end-joining pathways of DNA double strand break repair have overlapping roles in the maintenance of chromosomal integrity in vertebrate cells. EMBO J 1998;17:5497-508.

5. Essers J, van Steeg H, de Wit J, Swagemakers SM, Vermeij M, Hoeijmakers JH et al. Homologous and non-homologous recombination differentially affect DNA damage repair in mice. EMBO J 2000;19:1703-10.

6. Arnaudeau C, Lundin C, Helleday T. DNA double-strand breaks associated with replication forks are predominantly repaired by homologous recombination involving an exchange mechanism in mammalian cells. J Mol Biol 2001;307:1235-45.

7. Burkle A. Poly(ADP-ribosyl)ation. LANDES Bioscience; 2005.

8. Schreiber V, Dantzer F, Ame JC, de Murcia G. Poly(ADPribose): novel function for an old molecule. Nat Rev Mol Cell Biol 2006;7:517-28.

9. Scovassi AI, Poirier GG. Poly(ADP-ribosyl)ation and apoptosis. Mol Cell Biochem 1999;199:125-37. 
10. Malanga M, Pleschke JM, Kleczkowska HE, Althaus FR. Poly(ADP-ribose) binds to specific domains of p53 and alters its DNA binding functions. J Biol Chem 1998;273(19):11839-43.

11. Malanga M, Althaus FR. The role of poly(ADP-ribose) in the DNA damage signaling network. Biochem Cell Biol 2005;83(3):354-64.

12. Malanga M, Althaus FR. Poly(ADP-ribose) reactivates stalled DNA topoisomerase I and Induces DNA strand break resealing. J Biol Chem 2004;279(7):5244-8.

13. Smith LM, Willmore E, Austin CA, Curtin NJ. The novel poly(ADP-Ribose) polymerase inhibitor, AG14361, sensitizes cells to topoisomerase I poisons by increasing the persistence of DNA strand breaks. Clin Cancer Res 2005;11:8449-57.

14. Tentori L, Graziani G. Chemopotentiation by PARP inhibitors in cancer therapy. Pharmacol Res 2005;52:25-33.

15. Sandhu SK, Yap TA, de Bono JS. Poly(ADP-ribose) polymerase inhibitors in cancer treatment: a clinical perspective. Eur J Cancer 2010;46(1):9-20.

16. Cimmino G, Pepe S, Laus G, Chianese M, Prece D, Penitente R, Quesada P. Poly(ADPR)polymerase-1 signalling of the DNA damage induced by DNA topoisomerase I poison in D54(p53wt) and U251(p53mut) glioblastoma cell lines. Pharmacol Res 2007;55(1):49-56.

17. Gambi N, Tramontano F, Quesada P. Poly(ADPR)polymerase inhibition and apoptosis induction in cDDP-treated human carcinoma cell lines. Biochem Pharmacol 2008;75(12):2356-63.

18. Bryant HE, Schultz N, Thomas HD, Parker KM, Flower D, Lopez E et al. Specific killing of BRCA2-deficient tumours with inhibitors of poly(ADP-ribose) polymerase. Nature 2005;434(7035):913-7. 
19. Davis PL, Shaiu WL, Scott GL, Iglehart JD, Hsieh TS, Marks JR. Complex response of breast epithelial cell lines to topoisomerase inhibitors. Anticancer Res J 1998;18(4C):291932.

20. Tentori L, Muzi A, Dorio AS, Scarsella M, Leonetti C, Shah GM et al. Pharmacological Inhibition of Poly(ADP-ribose) Polymerase (PARP) Activityin PARP-1 Silenced Tumour Cells Increases Chemosensitivity to Temozolomide and to a N3-Adenine Selective Methylating. Agent. Curr Cancer Drug Targets 2010;10(4):368-83.

21. Tice RR, Agurell E, Anderson D, Burlinson B, Hartmann A, Kobayashi et. al. Single cell gel/comet assay: guidelines for in vitro and in vivo genetic toxicology testing. Environ Mol Mutagen 2000, 35, 206-21.

22. Giansanti V, Dona` F, Tillhon M, Scovassi AI. PARP inhibitors: New tools to protect from inflammation. Biochem Pharmacol 2010 Apr 22 [Epub ahead of print] PMID: 20417190.

23. Rouleau M, Patel A, Hendzel MJ, Kaufmann SH. Poirier GG. PARP inhibition: PARP1 and beyond. Nat Rev Cancer 2010;10:293-301.

24. Yelamos J, Schreiber V, Dantzer F. Toward specific functions of poly(ADP-ribose) polymerase-2. Trends Mol Med 2008;14(4):169-78.

25. Hastak K, Alli E, Ford JM. Synergistic chemosensitivity of triple-negative breast cancer cell lines to PARP inhibition, gemcitabine and cisplatin. Cancer Res 2010 Aug 26. [Epub ahead of print] PMID: 20798217.

26. Feeney GP, Errington RJ, Wiltshire M, Marquez N, Chappell SC, Smith PJ. Tracking the cell cycle origins for escape from topotecan action by breast cancer cells. $\mathrm{Br} \mathrm{J}$ Cancer 2003;88(8):1310-7.

27. Tuguri S, Crabbé L, Conti C, Tourrière H, Holtgreve-Grez H, Jauch A et al. Topoisomerase I suppresses genomic instability by preventing interference between replication and transcription. Nat Cell Biol 2009;11(11):1315-24. 
28. Wieler S, Gagne’ JP, Vaziri H, Poirier GG, Benchimol S. Poly(ADP-ribose) Polymerase-1 Is a Positive Regulator of the p53-mediated G1 Arrest Response following Ionizing Radiation. J Biol Chem 2003;278: 18914-21.

29. Tomicic MT, Christmann M, Kaina B. Topotecan-triggered degradation of topoisomerase I is p53-dependent and impacts cell survival. Cancer Res 2005;65(19):8920-6.

30. Rodriguez-Hernandez A, Brea-Calvo G, Fernandez-Ayala DJM, Cordero M, Navas P, Sanchez-Alcazar JA. Nuclear caspase-3 and capase-7 activation, and Poly(ADP-ribose) polymerase cleavage are early events in camptothecin-induced apoptosis. Apoptosis 2006;11:131-39. 


\section{LEGENDS TO FIGURES}

Figure 1 - Cell cycle analysis of $\mathrm{HeLa}^{\mathrm{Babe}}$ and $\mathrm{HeLa}^{\mathrm{SiP}-1}$ cells treated with TPT and PJ34 as single agents or in combination.

Babe and SiP-1 cells were treated for $1 \mathrm{~h}$ with TPT $(0.2-0.4-1.25-2.5-5 \mu \mathrm{M})$ in combination or not with PJ34 $(5 \mu \mathrm{M})$ and left to recover for $24 \mathrm{~h}$ in fresh medium in the presence or not of PJ34. The results are expressed as percentages of cells in the G1, S and G2/M phase of the cell cycle. Data refer to one out of three experiments giving similar results.

Figure 2 - Cell death analysis of HeLa cells subjected to TPT and PJ34 single and combined treatments.

Babe and SiP-1 cells were treated for $1 \mathrm{~h}$ with $1.25 \mu \mathrm{M}$ TPT in combination or not with $5 \mu \mathrm{M}$ PJ34 and left to recover for $72 \mathrm{~h}$ in fresh medium in the presence or not of PJ34. Flow cytometric determination of DNA content after PI staining is shown. The percentage of cells in the sub diploid (subG1) peak is indicated. Data refer to one out of three experiments giving similar results.

Figure 3 - DNA damage in HeLa ${ }^{\text {Babe }}$, $\mathrm{HeLa}^{\mathrm{SiP}-1}$ and MCF7 cells subjected to TPT+/-PJ34 treatment.

A: Hundred cells $24 \mathrm{~h}$ after $1 \mathrm{~h}$ treatment with $10 \mu \mathrm{M}$ TPT $+/-5 \mu \mathrm{M}$ PJ34 were analysed by alkaline comet assay on a fluorescence microscope (Nikon) and quantitative assessment of DNA damage was performed using Comet Score. The olive tail moment is reported as a mean of three different experiments +/- S.E. 
B: Western Blot analysis of $\gamma \mathrm{H} 2 \mathrm{AX}$ levels in $\mathrm{HeLa}^{\mathrm{Babe}}$ and $\mathrm{HeLa}^{\mathrm{SiP}-1}$ cell nuclei treated $1 \mathrm{~h}$ with $10 \mu \mathrm{M}$ TPT and allowed to recover in fresh medium in the presence or not of 5 $\mu \mathrm{M}$ PJ34 for $72 \mathrm{~h}$. Actin was used as loading control.

Figure 4 - PJ34-dependent inhibition of PAR synthesis in $\mathrm{HeLa}^{\mathrm{Babe}}$ and $\mathrm{HeLa}^{\mathrm{SiP}-1}$ cells.

Cells were resuspended in lysis buffer, sonicated and incubated with $50 \mu \mathrm{M}\left[{ }^{32} \mathrm{P}\right]-$ $\mathrm{NAD}^{+}+/-5 \mu \mathrm{M}$ PJ34 as described in Materials and Methods.

A: Autoradiographic analysis of whole cell protein after SDS-PAGE and electroblot on PVDF.

B: Immunodetection of PARP-1 and GAPDH on the blot shown in A.

Figure 5 - TPT-dependent PARP activation in MCF7 cells.

Following treatment with $10 \mu \mathrm{M}$ TPT+/-PJ34 and recovery for $24 \mathrm{~h}$ in fresh medium in the presence or not of $5 \mu \mathrm{M} \mathrm{PJ} 34$, cells were incubated with $0.125 \mu \mathrm{M}\left[{ }^{32} \mathrm{P}\right]-\mathrm{NAD}^{+}$, as described in Materials and Methods.

A: Autoradiographic analysis of whole cell protein after SDS-PAGE and electroblot on PVDF.

B: Immunodetection of PARP-1, PARP-2 and GAPDH on the blot shown in A.

Fifty ng of human recombinant PARP-2 (hrPARP-2) was also loaded as a standard.

Figure 6 - Western Blot analysis of PARP-1, TOP1, p53 and p21 in MCF7 cells.

Cells were treated with $10 \mu \mathrm{M}$ TPT for $1 \mathrm{~h}$ and allowed to recover in fresh medium in the presence or not of $5 \mu \mathrm{M}$ PJ34 for the indicated times. GAPDH was used as loading control. 
Figure 7 - Western blot analysis of PARP-1, TOP1, p53 and p21 in HeLa ${ }^{\text {Babe }}$ and HeLa ${ }^{\text {SiP-1 }}$ cells.

Cells were treated with $10 \mu \mathrm{M}$ TPT for $1 \mathrm{~h}$ and allowed to recover in fresh medium in the presence or not of $5 \mu \mathrm{M}$ PJ34 for the indicated times. GAPDH was used as loading control.

Figure 8 - Densitometric analysis of p53 levels in HeLa cell samples.

After immunodetection on western blots, band intensities were quantified by scanning densitometry. Data, expressed as Arbitrary Densitometric Units (ADU), were normalized to the internal control GAPDH. Shown are the mean of three different experiments +/-S.E.

Figure 9 - Western Blot analysis of PARP-1 and BAX in HeLa and MCF7 cells.

Cells were treated with $10 \mu \mathrm{M}$ TPT for $1 \mathrm{~h}$ and allowed to recover in fresh medium in the presence or not of PJ34 for $72 \mathrm{~h}$. GAPDH was used as loading control. 


\section{HeLa $^{\text {Babe }}$}

$\square \mathrm{G} 1$ 국 $\mathrm{S}$ G2/M

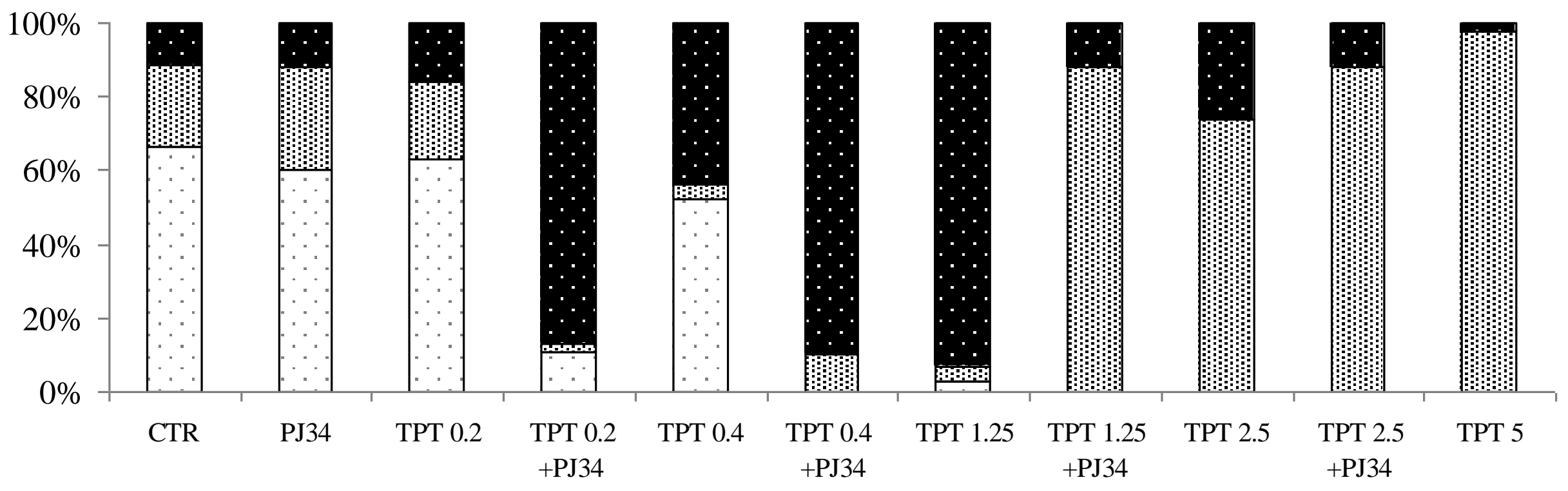

\section{HeLa $^{\text {SiP-1 }}$}

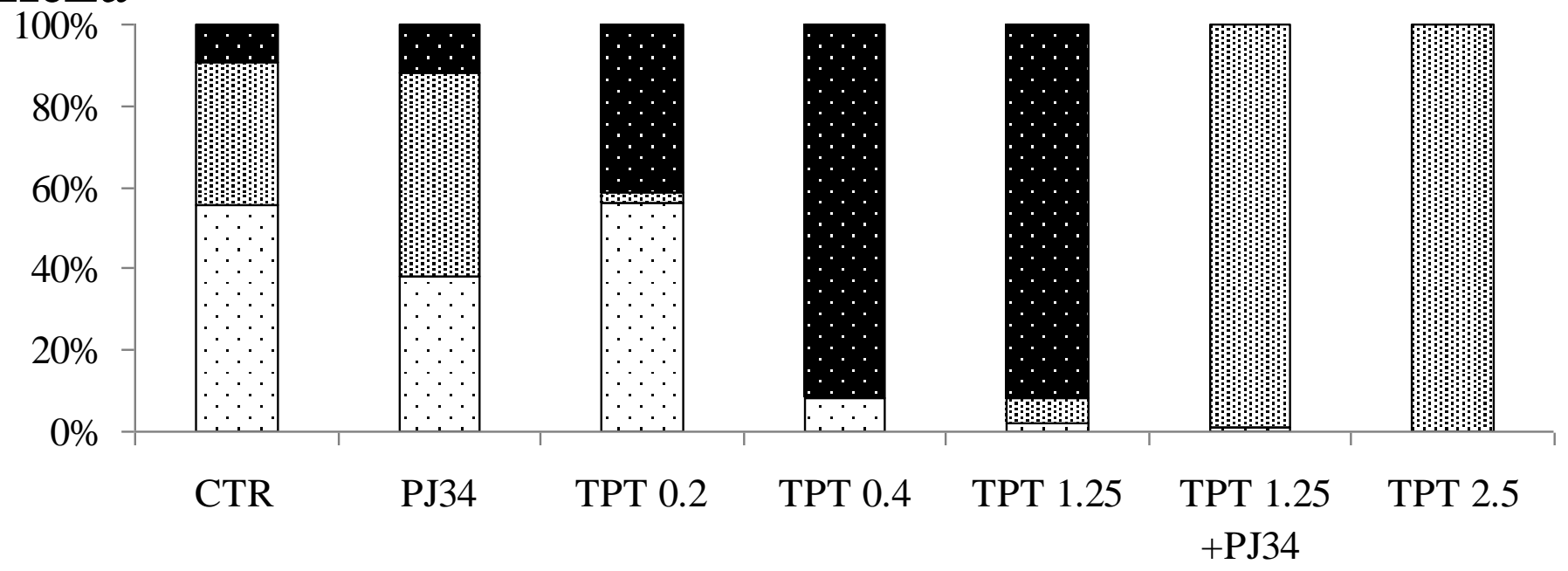

Figure 1 


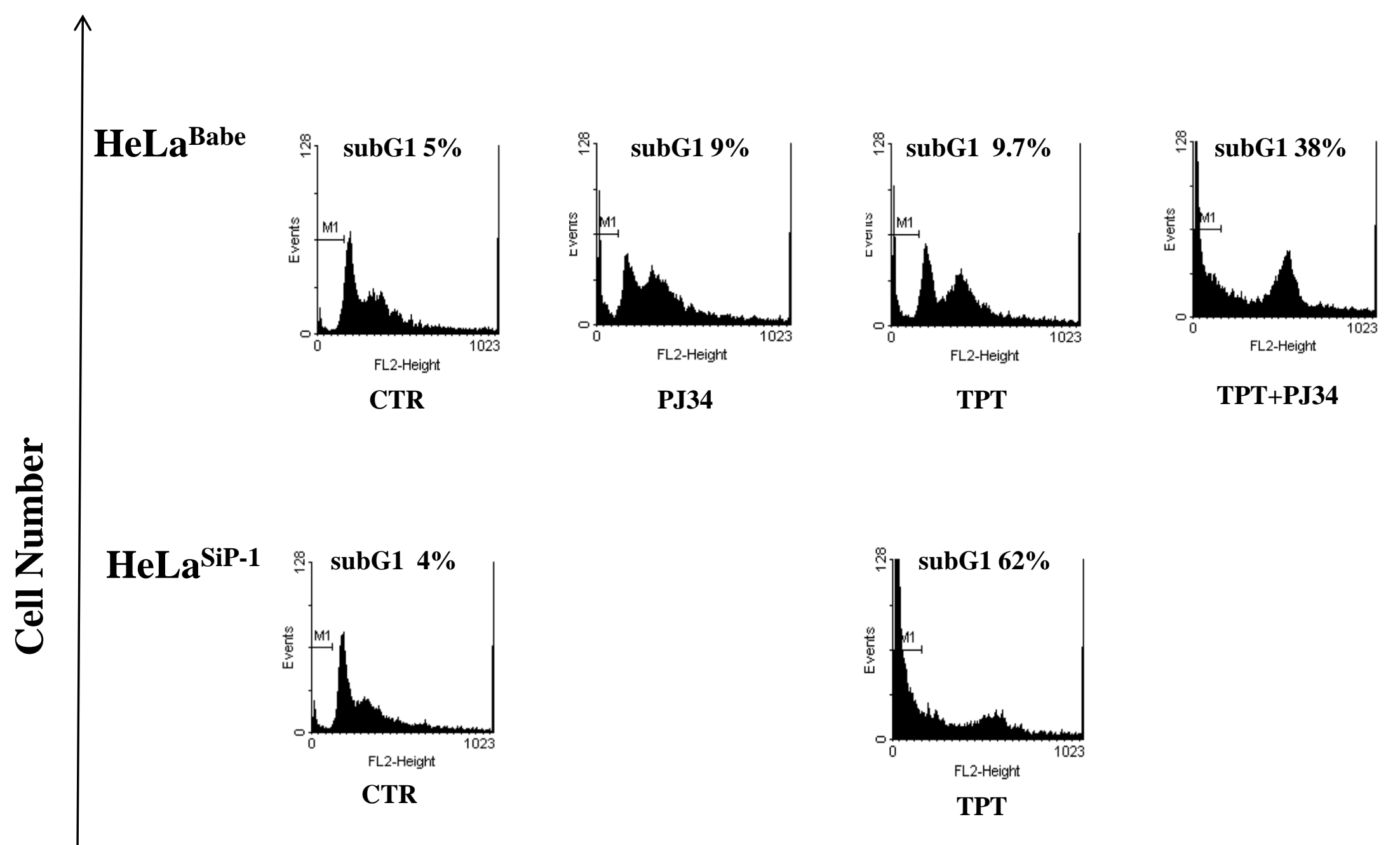

DNA content

Figure 2 

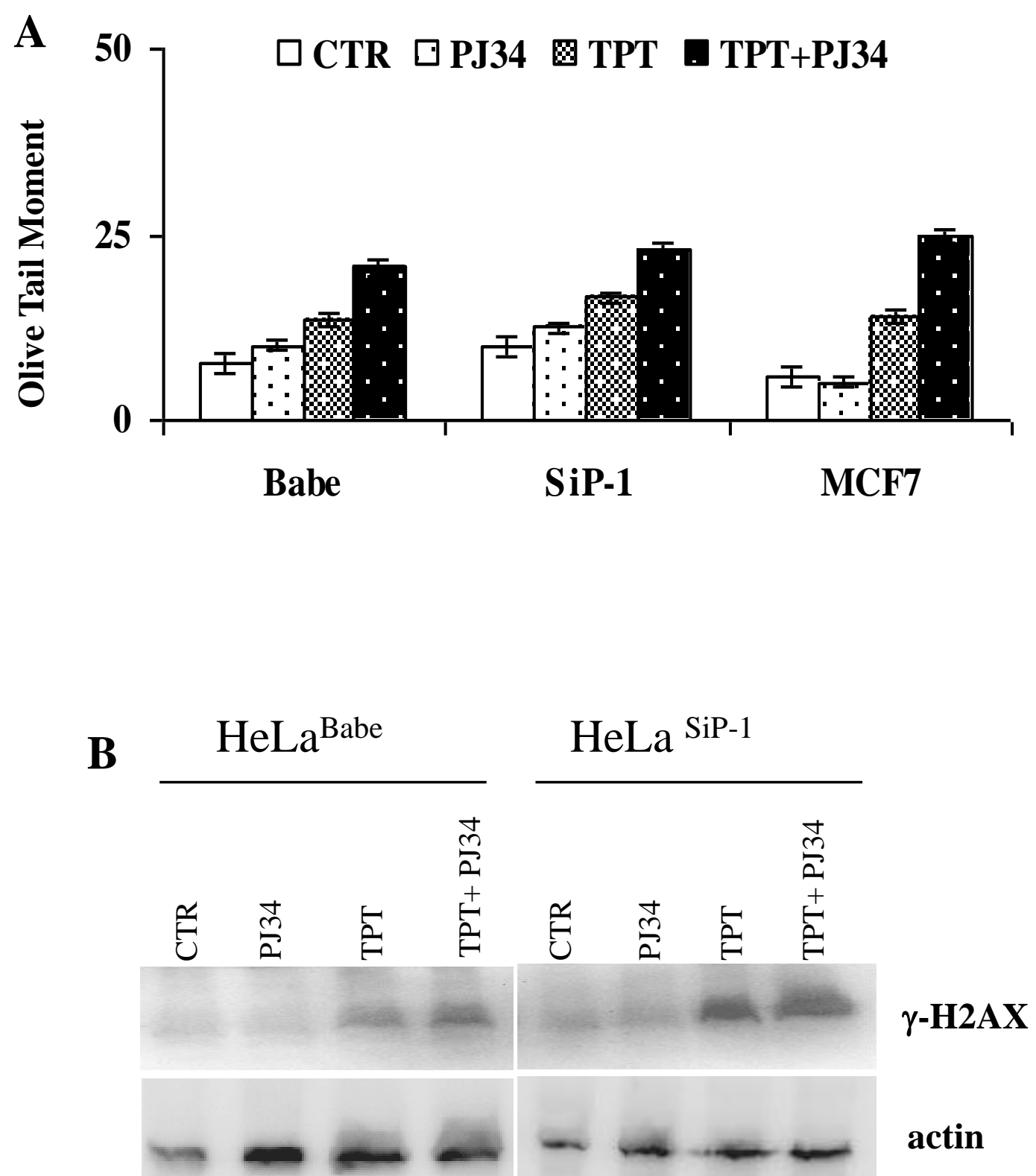

Figure 3 


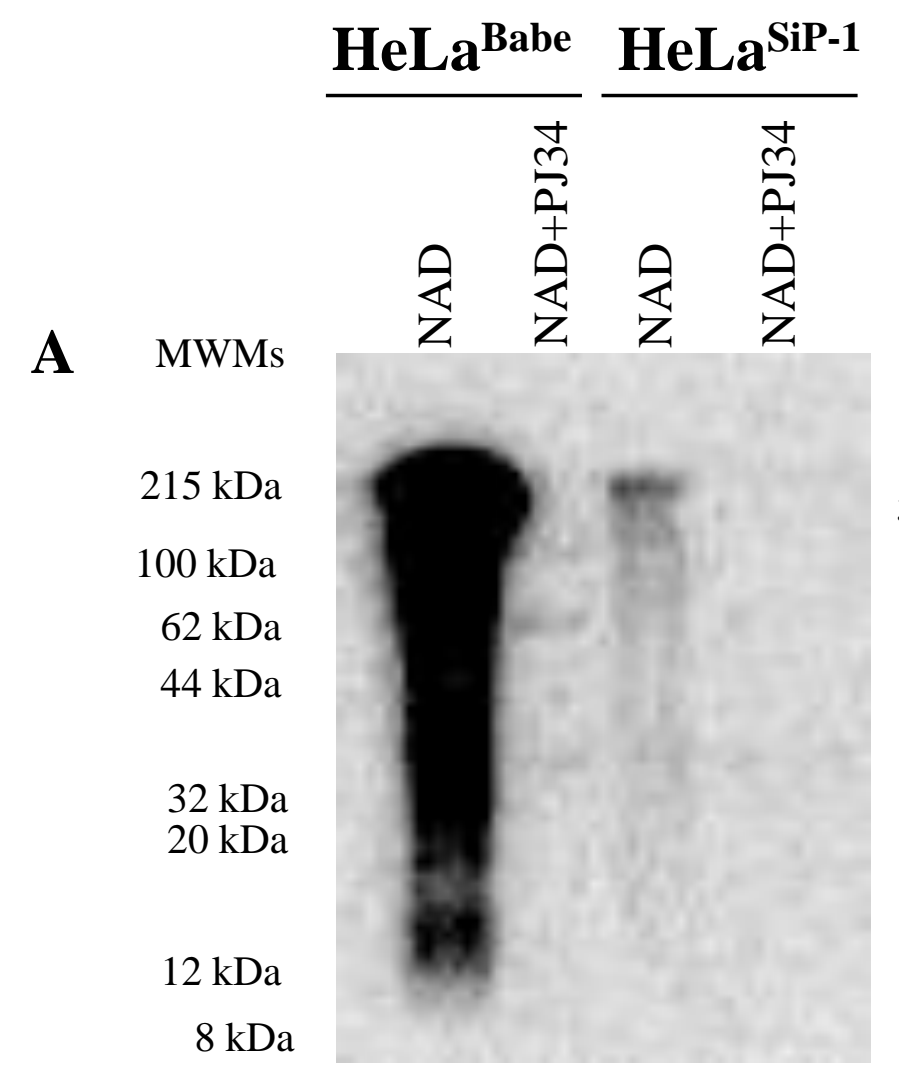

32P-PAR

B

PARP-1

Figure 4

\section{GAPDH}




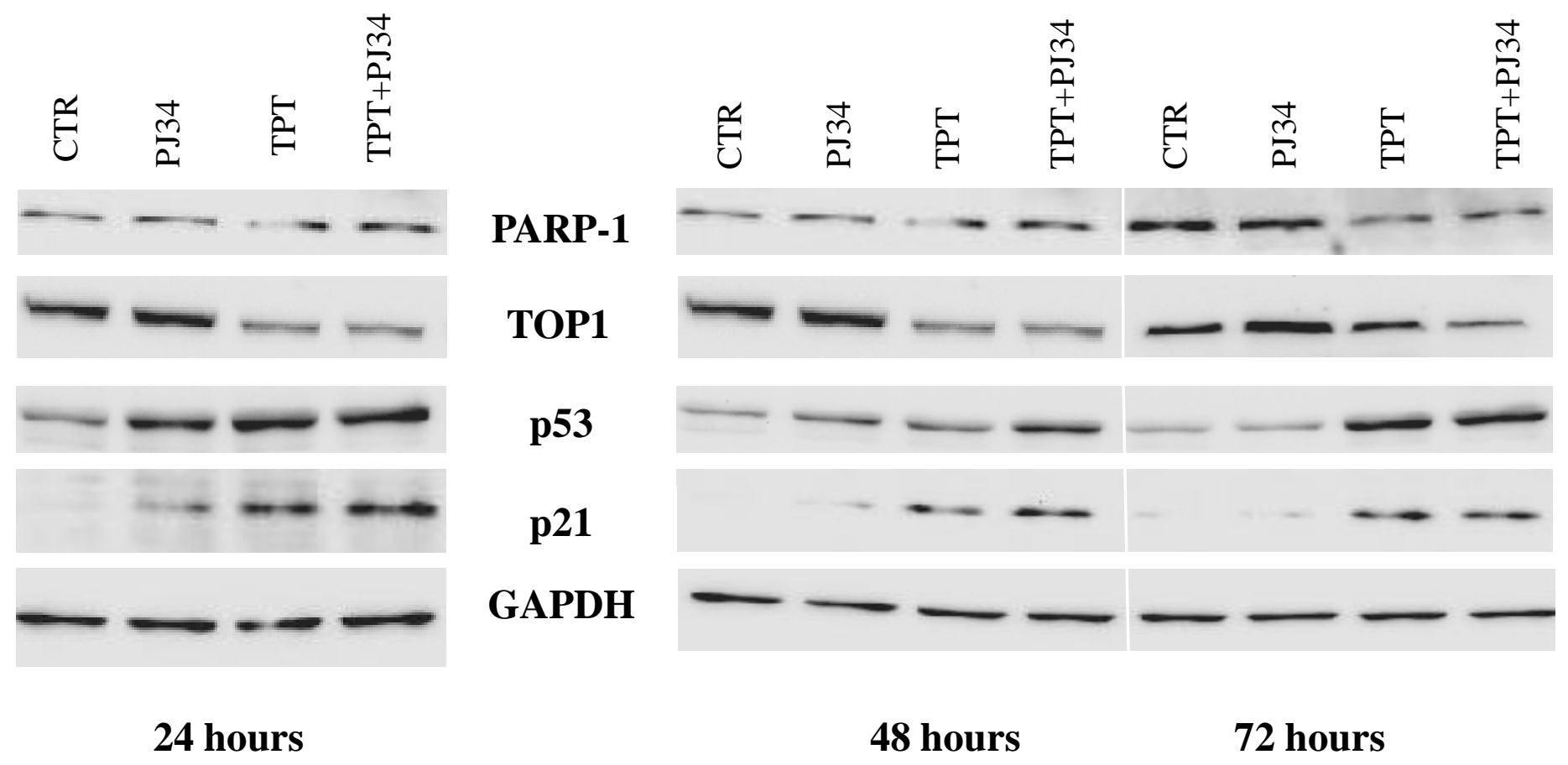

Figure 6 


\begin{tabular}{|c|c|c|c|c|c|c|c|c|}
\hline \multicolumn{4}{|c|}{ HeLa ${ }^{\text {Babe }}$} & \multicolumn{4}{|c|}{ HeLa ${ }^{\mathrm{SiP}-1}$} & \\
\hline 苞 & $\stackrel{+}{m}$ & $\overline{\mathbf{Q}}$ & $\begin{array}{l}\stackrel{+}{0} \\
\stackrel{2}{2} \\
+ \\
\stackrel{+}{E}\end{array}$ & 卢 & $\stackrel{+}{a}$ & $\hat{2}$ & $\begin{array}{l}\stackrel{+}{m} \\
\stackrel{a}{a} \\
+ \\
\stackrel{+}{a}\end{array}$ & \\
\hline- & - & - & - & & & & & PARP-1 \\
\hline- & $\longrightarrow$ & - & - & 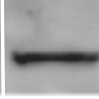 & - & & 5 & TOP1 \\
\hline & - & $\longrightarrow$ & $\longrightarrow$ & - & $\longrightarrow$ & - & $\longrightarrow$ & p53 \\
\hline- & - & - & 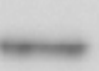 & & - & - & - & GAPD \\
\hline
\end{tabular}

\section{4 hours}

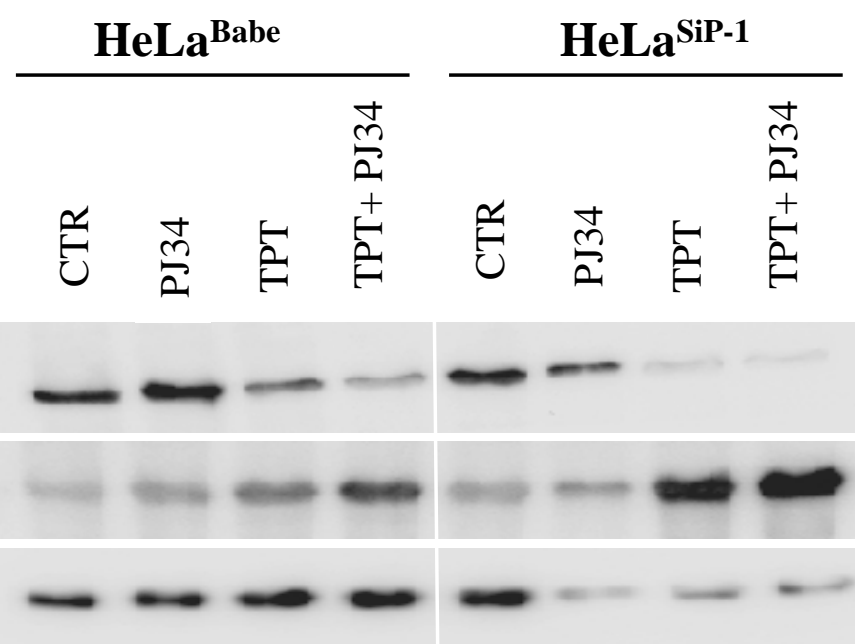

48 hours

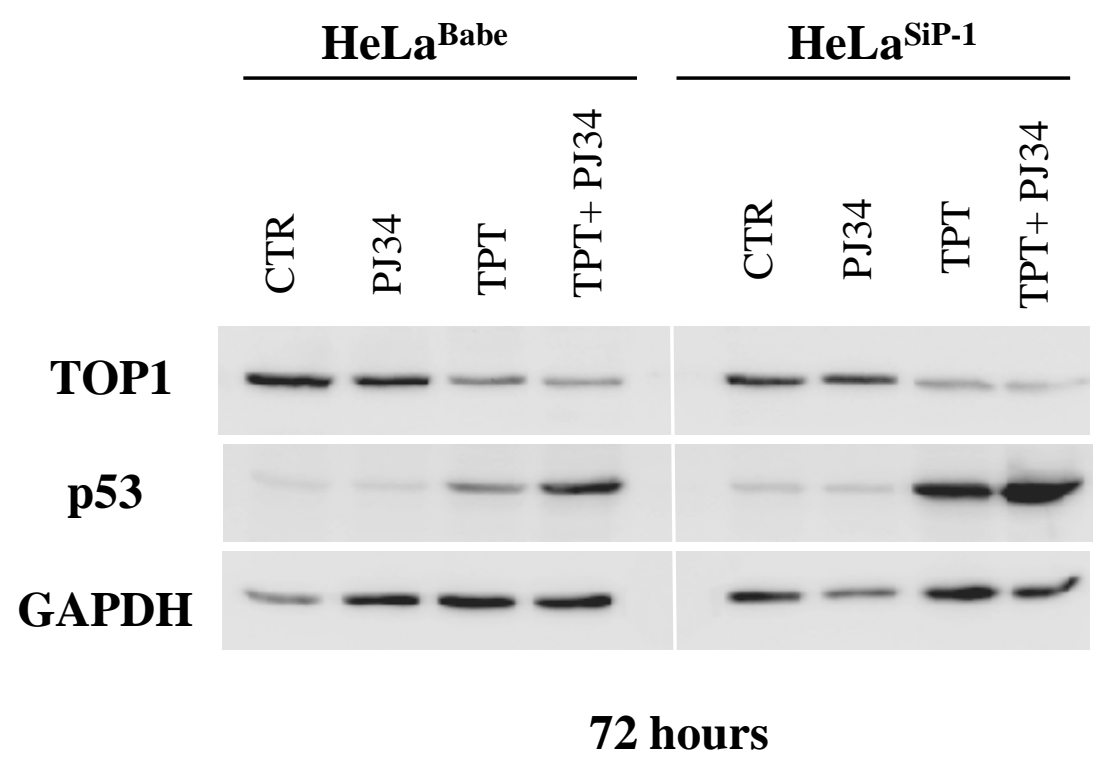

\section{Figure7}




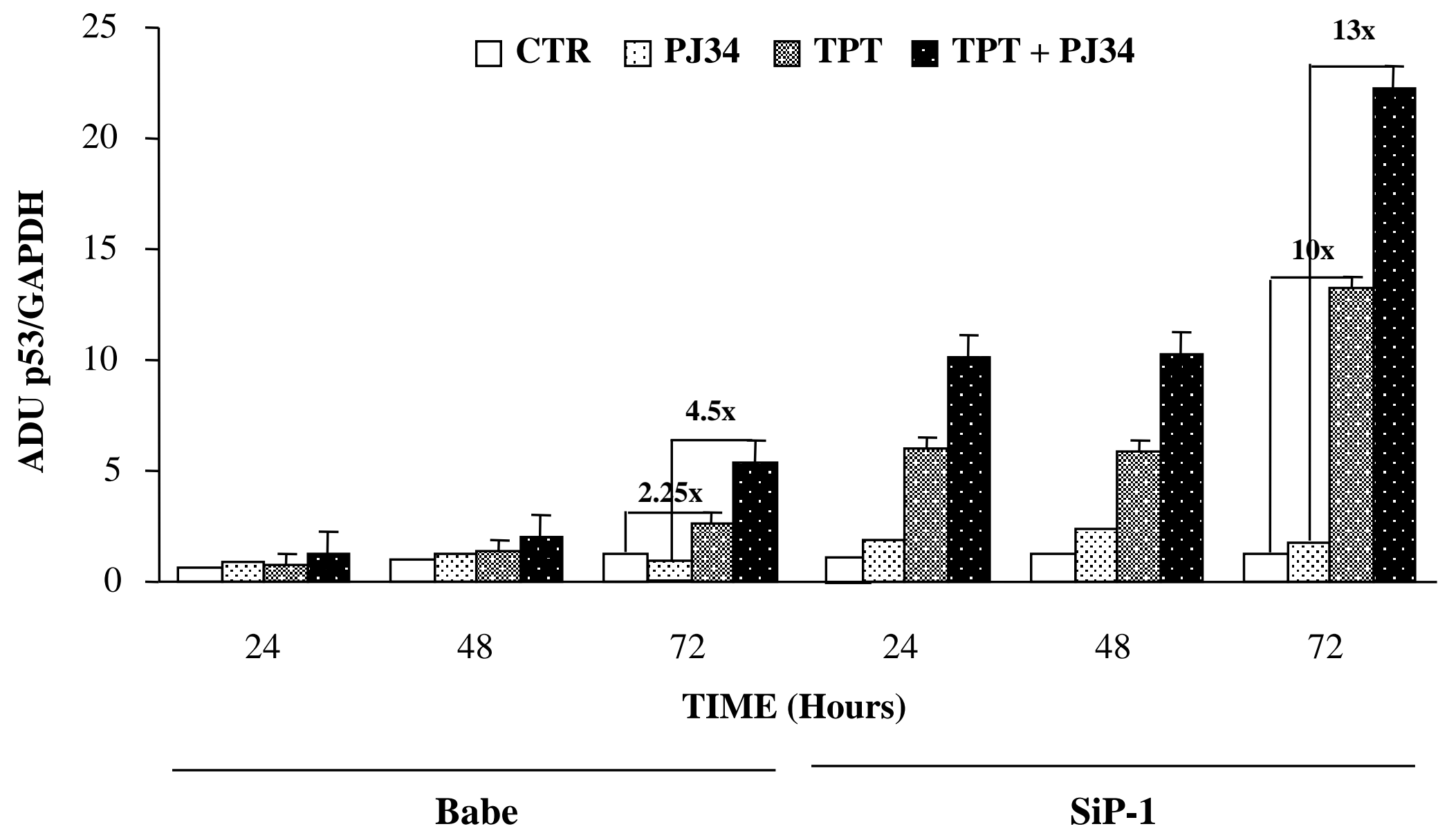

Figure 8 

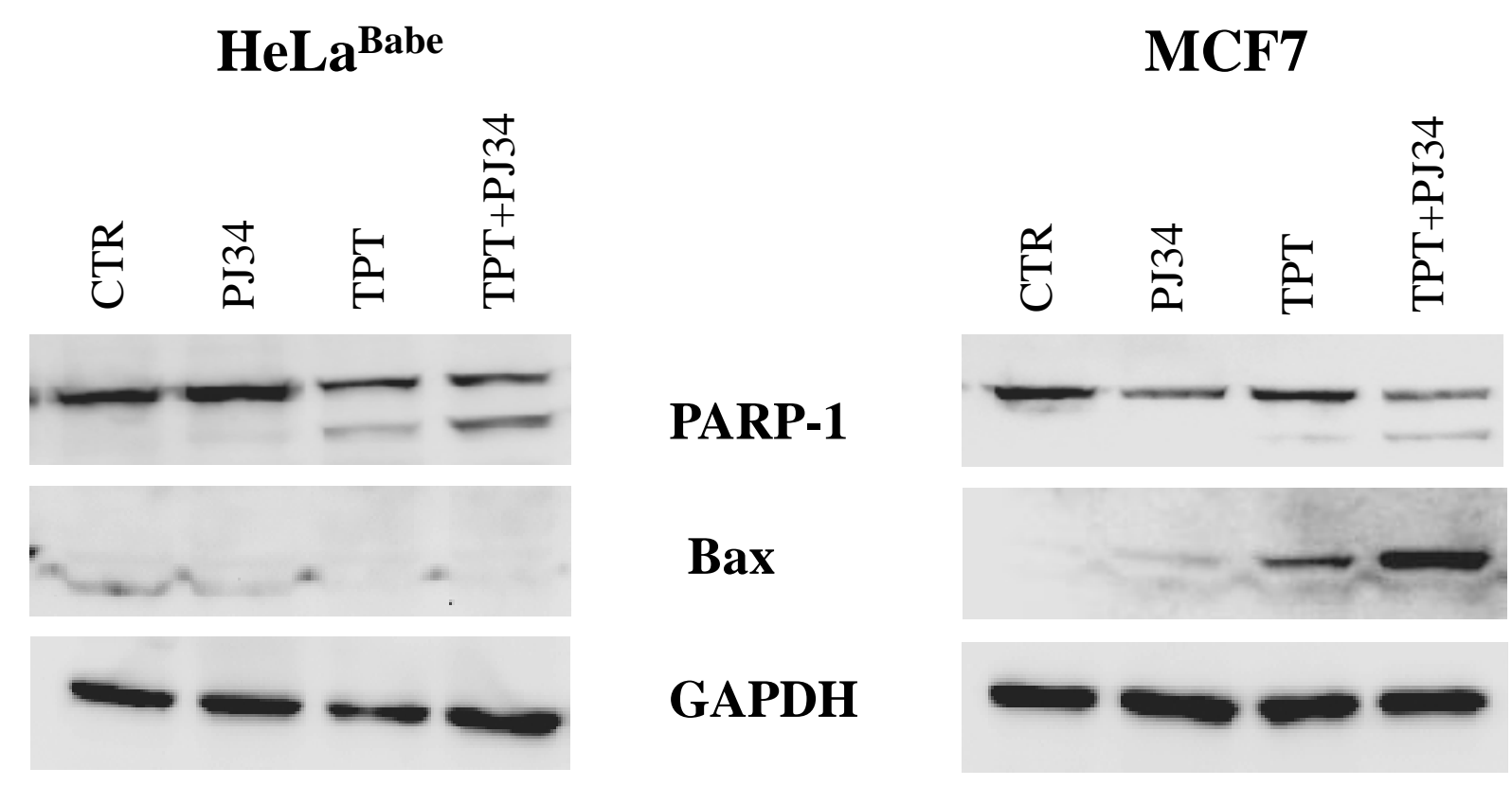

Figure 9 


\section{${ }^{\star}$ Graphical Abstract}

Topotecan-dependent DNA damage is signaled by PARP-1 and -2 activation and p53 up-regulation in HeLa and MCF7 cells.
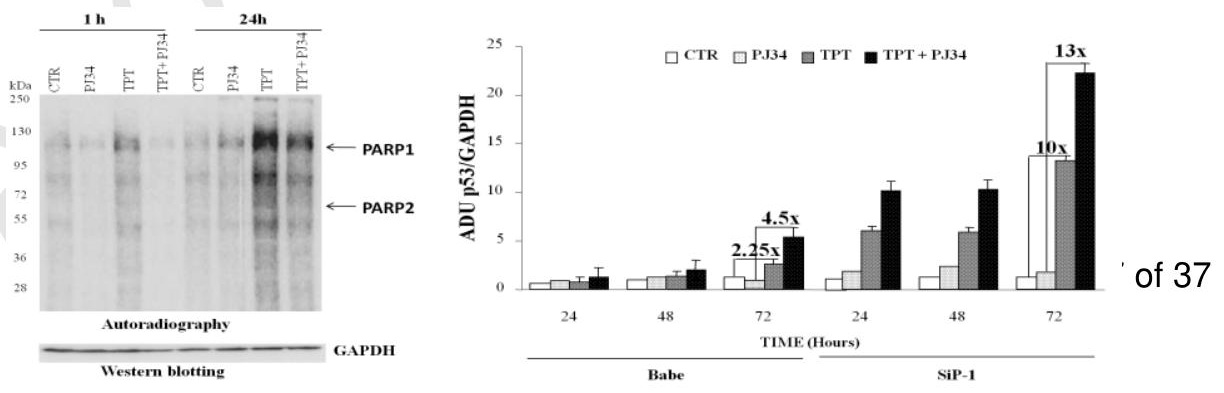